\title{
CITIZEN JOURNALISM AND VILLAGE EMPOWERMENT AT CANGKUDU VILLAGE, TENGERANG BANTEN-INDONESIA
}

\author{
La Mani, Gayes Mahestu, Mungky Diana Sari, Tri Adi Sumbogo \\ Bina Nusantara University, Indonesia. \\ la.mani@binus.edu
}

\begin{abstract}
The implementation of Community Service Program in long terms aimed to produce village communication media in the form of village newspaper and website. This village communication media is essential as a media to deliver the information of the village development program implementation and various village's potential to the village stakeholders. This village communication media also functions as education media to increase the villagers' awareness regarding various actual issues and village development framework. Method used was fact finding. The data collection was done through literature study, interview and participation observation to the youth villagers (Karang Taruna) and the village apparatus. Technical assistance was performed through a series of journalistic workshop and media production as well as media distribution to various villages' government stakeholders. The result of this community service was the Village Communication Media, of which one of them is the village newspaper and its development in the form of dynamic website which can be managed by Karang Taruna and the village apparatus.
\end{abstract}

Keywords: Villagers’ Journalism, Village Newspaper, Village Youth, Village Empowerment

\section{Introduction}

The phenomenon of mass media ownership in Indonesia encounters asymmetry among the society, authority and entrepreneur. Mass media is only owned by the elites who have power and authority in terms of economy and politic. Thus, it causes the community to become the consumer only and are is able to become the message producer of the mass media. Worries of the mass media emergence is the maintenance of the social order as the effect of politic economy agenda and media dominance which has become the reality in Indonesia. Ideally, media becomes the control or the watchdog of the state system, government and social deviance. However, such role fades. Media is even silent on the deviance done by the authority. Thus, in order to balance the hegemony and conspiracy between the media and the authority, then the stages must be covered to develop the civil community capacity in producing positive, critical and inspiring content. Concrete stages that can be covered is by improving the community capacity in their journalistic skill so that the community empowers in providing information.

The importance of villagers' empowerment in the ownership of media is in line with the Law No. 6 of 2014 concerning village. This regulation directs the village area development in the process of village development to become more independent in terms of social, economy, politics and culture fields. The mandate of this village law is to improve the community participation in developing the village physically and non-physically. One of the aspects that needs to be developed is the media ownership or information availability which covers the village development planning and the programs that have been done by the village government and the villagers. One of the media that can be used is through "Village Newspaper" both in conventional and digital formats. Thus, correct information needs to be produced through the correct way as well.

Problem encountered by the government of Cangkudu Village to produce newspaper is the limitation of human resource and the lack of knowledge owned in making the village newspaper. Thus, solution taken by the government of Cangkudu Village is developing partnership and cooperation with Universitas Bina Nusantara to realize the vision of the village government. Universitas Bina Nusantara through the Magister Program of Communication Studies and the Department of Communication Studies has willing to teach and accompany the newspaper production so that it can be realized. Universitas Bina Nusantara party has also committed and willing to provide lecturers who are competent in terms of Journalism both in terms of theoretical and practical. Meanwhile, Cangkudu village government party has willing to provide human resource, room and building as well as its facilities for the village newspaper secretariat. In order to support the process of journalistic learning and village newspaper production, Cangkudu Village government provides library as reading room and writing process references. Through the infrastructure support from Cangkudu Village Government, then chance of the newspaper production can be realized.

Universitas Bina Nusantara along with Cangkudu Village initiated to develop collaboration to start to develop the village newspaper in Cangkudu Village as information media between the village government and its 
villagers. The improvement of the villagers and the young villagers' capacity to produce good and correct content needs to be done. The villagers' empowerment in terms of mastering the communication skills need to be done in order to develop the villagers' communication competence who later would produce the village newspaper in Cangkudu Village, Tangerang, Banten.

\section{Results and Discussion}

\section{a. Brief Profile of Cangkudu Village}

Cangkudu Village is one of the villages in the administrative area of Balaraja Sub-District. Geographically, Cangkudu Village is in the northern of Tangerang District with the area width of 42,000 km2 (11.95\%) from the total width of Balaraja Sub-District. In terms of its villagers' number, Cangkudu Village consists of 19,036 people in which there are 9,756 males and 9,277 females distributed in 37 RT and 4 RW. Balaraja Sub-District is a sub-district where many companies are built, in which there are 34 companies. Among those companies, 7 village's companies operate in Cangkudu Village with the number of employees is 26,278 people (Data of Cangkudu Village, 2017). The companies which operate in Cangkudu Village belongs to manufacture industry from Indonesia or foreign company (multinational corporation/MNC).

Seen from the leadership aspect, Cangkudu Village is recently leaded by a professional and intellectual named Haji Amir Hamzah, SE, MM. Generally, the village chief in thousand industry village is a figure or strong local person. In terms of leadership period, Haji Amir Hamzah was chosen in 2013 and changed Cangkudu Village into modern, advanced, and developed village government. Haji Amir Hamzah leadership is considered as revolutionary and visionary. The priority of community service is conducted openly and one door in the village office. There is no "village office or draft runs". All bureaucracy must involve the administrators of RT and RW. In order to monitor the performance of village staff, the village office has been equipped by the application of electronic absence. In addition, in order to support the creation of bureaucracy reformation implementation which is orderly, optimal, and in accordance with the Standard Operational Procedure (SOP), Cangkudu Village provides office and its complete facilities. In order to improve the public service operational, the village government provides motorcycle facilities for several villages' apparatuses. Village office equipped by its representative facilities is provided so that all village apparatuses can work comfortably and calmly. Haji Amir Hamzah leadership in managing the human resource gives worthy incentive to the village apparatus so that they can work with prime spirit, responsibility, and service to the villagers. The incentive is given to RT/RW, 60 cadres of integrated service centre, community protection staff and village apparatus.

Cangkudu Village has been recognized as the best village in Banten Province, even in Indonesia in 2015. In addition, Cangkudu Village also becomes the example of Village-Owned Enterprise (BUMDES) in Indonesia. In order to complete his village success, the chief of Cangkudu Village develops the mission of the availability of village newspaper. For Haji Amir Hamzah, there are not many villages which have newspaper and managed it independently in Indonesia. The primary purpose of the village government in making newspaper is to deliver all information related to Cangkudu Village, besides other information which is important to be known by the villagers of Cangkudu Village and community in general. The realization of this desire needs human resource who is skilled in terms of journalism for the villages' apparatus and Cangkudu Villager who have been chosen. In this research, Cangkudu Village chose Karang Taruna group as the implementers of the village newspaper production. The vision of Cangkudu Village Government was welcomed by the lecturers of Universitas Bina Nusantara, especially Magister Study Program of Communication Studies and Department of Communication Studies to collaborate and develop cooperation to realize this vision. Skill given were: journalistic essence explanation, news value, news writing process, journalistic language, journalistic ethic, and community media management. According to Romel Tea (2014), news production process includes news planning, news hunting, news writing and news editing.

\section{b. Villagers' Journalism Existence in Cangkudu Village}

Journalism means writing for newspapers or magazines. It is the communication of information through writing in periodicals and newspapers. The people have an inborn desire to know what's novel or new. This curiosity is satisfied by the journalists through their writing in the newspapers and journals on current affairs and news. Journalism is the occupation of reporting, writing, editing, photographing or broadcasting news or of conducting any news organization as a business. The word "Journalism" is derived from the word "Journal" which means a daily register or a diary - a book containing each day's business or transactions. This includes newspapers no matter whether they are published daily or weekly. It also means a magazine to whatever section of the audience it caters to (Umar Farooq, 2015).

Shayne Bowman and Chris Willis defined Citizen Journalism as "Citizen action in playing active role in the process of collection, reporting, analyzing, and delivering the news and information". Citizen Jounalism has 
other terms such as Public Journalism, Advocate Journalism, Participative Journalism, Participative Media, Open Source Report, Distributed Journalism, Community Media, and Grassroots Journalism. The initial idea of village newspaper in Cangkudu Village starts from the understanding that village newspaper can act as a communication media between the stakeholders of the village and information means regarding the village local potential. Thus, science and technology applied in the accompaniment and empowerment of the villages includes the basic of journalism. Knowledge and technology which are important to be learned by the empowerment program target group is the stages of making/writing news. The following is the stages of making/writing news:

1) Collecting event fact and data consisting of actual, factual, important and interesting news by fulfilling six elements of news, those are $5 \mathrm{~W}+1 \mathrm{H}$ (What does happen, Who is involved in the event, where does it happen, when does it happen, why does it happen, and how is the process of the event);

2) Fact and data that has been collected is written based on the formulation of $5 \mathrm{~W}+1 \mathrm{H}$ using journalistic language. It contains specific and communicative elements. Specific is signed by short, standard, and simple sentences. Communicative is signed by clear language, straight to the point, and easily understood by common people.

3) The composition of news script is Head (title), Date Line which is the name of the place where the event happens or where the news is made. Lead or the first paragraph contains the most important part or the most interesting part, while Body (Content) is the explanation of the lead (Romel Tea, 2014).

Journalistic approach is expected to have an important role in distributing message or news to the public. Meanwhile, the newspaper production of Cengkudu Village is implemented with the consideration of the team capability and the villagers' need. Thus, the following purposes are made:

\section{1) Village Information Media}

The primary role of journalistic is providing information. Village newspaper has indirect role in the process of social changes occur in the community. Through various information which will be presented along with its development idea, journalistic is able to affect, stimulate and drive the community to involve actively in the development activity in all sectors. Agenda setting which is made through the news, feature, and report are expected to be the source for Cangkudu villagers so that it can stimulate, affect and change the behavior as well as drive the community positively, for example is the efforts to drive the community to be actively involved in the development activity expected to create village free from waste. Village free from waste program also becomes a part of the cooperation between the Department of Communication Studies and Cangkudu Village.

2) Educating the Community

The role of village newspaper as the villagers' educator and the presentation of various educating knowledge, enlightens and gives new knowledge and insight related to the village development. Success story and other contents which are useful to improve the life's value for the readers. Through various information presented by Karang Taruna team of Cengkudu Village, it is expected that it can develop new aspiration among the community. Besides, Cangkudu village newspaper which also contains information regarding the activities performed by the village government can be a control on the local village government.

3) Entertainment Provider

In addition as informative and educating presentation, Cangkudu village newspaper certainly also presents entertaining contents in order to attract the villagers' interest. Entertaining village' newspaper can also be reliever from work hectic or other activities. As examples in delivering entertaining creations are in the form of comedy cartoon, caricature, comic or quotes which have the characteristics of human interest.

\section{c. The Implementation of Community Service}

This Community Service Activity was conducted by a team consisting of four lecturers which focuses on the continuation of Cangkudu Village newspaper making program, West Balaraja, Banten Province. The implementation of community service in Cangkudu Village has been done since 2017. The process of building understanding and assessment of needs was conducted along with the implementation of leadership communication research in developing village enterprise (La Mani and Tri Adi Sumbogo). That research was then continued by another research performed in 2018 about Social Capital and Village Development (La Mani) and the Adoption of Communication and Information Technology Innovation in Improving Community Service in village (Gayes Mahestu and Tri Adi Sumbogo).

Community service was started by Basic Journalistic Workshop (Mungky Diana Sari, Gayes Mahestu, Tri Adi Sumbogo, La Mani). Assessment has been performed since 2017 along with the research conducted in Cangkudu Village. Assessment result found that there is need from the village government to have village communication 
media as instrument to inform development messages to the villagers and relevant stakeholder. At the end of 2018, the making of village newspaper as an answer to Cengkudu villlagers' need on the information and literacy was executed. The maturation of idea, permit, cooperation, and implementation process has been taken. Preparing the equipment was the first obstacle encountered. The mean of equipment is the team which later would be the journalist team of Cangkudu Village.

The activity implementation was conducted in three parts as follow:

1) F2F Meeting

Face to face meeting was conducted in accordance with the preparedness of the village and the journalist team, in which there is at least one a month to know the development of the program implementation. The meeting was conducted to hold the workshop and training aiming to improve the capacity of the youth villagers' writing

2) Online Group

Making online group through social media such as WAG, LINE Group or in other forms agreed together in order to know the daily/weekly progress. In its practice, it was agreed to make WAG with the name of "Cangkudu Ceria".

3) Implementation Assistance

Lecturer and university students directly participate in assisting the young villagers of Karang Taruna to ensure the technical activities of the village newspaper production in the field so that it was implemented in accordance with the plan.

The implementation of Cangkudu Village newspaper was started from trainings related to journalistic writing to the team chosen. This team was formed so that there is a group of villagers who have skills as village journalist. The process of workshop and filtering of village newspaper team was conducted for three days in the middle of November 2018 in Cangkudu Village office. The workshop was participated by no more than 15 participants. The number of participants of this activity was less than the planning since it was conducted during working days and hours. There were many participants who could not participate in the socialization event. In the initial planning, the activity would present 25 participants focusing on the introduction of journalistic and how to make a light article in the form of feature.

For two days, the participants were given theory with a little practice. At the last day, the participants focused fully on the practice. According to the result obtained, generally, the participants could comprehend and understand how to make light article. This activity was planned not only once, but there would be further program to make light news (feature) and agenda-setting. The second briefing was conducted during the agenda setting training of news at early May 2019. The participant actively participated in writing agenda setting of news coverage assisted by the lecturers of Universitas Bina Nusantara and the students of mass communication department. This process was continues by informal and nonformal assistance planned, while online assistance was done through online group (WA Group). The lecturer team monitored the activity of journalistic team through online media and field trip.

\section{d. Inhibition and Obstacle of Village Empowerment in Villagers' Journalism of Cangkudu Village}

The idea of the existence of villagers' journalism in Cangkudu Village has an important role, primarily in developing the villagers' capacity to be involved as journalist. However, the training held by the Lecturers of Universitas Bina Nusantara encountered obstacles. The obstacles occurred were:

1) The journalist personnel from the members of Karang Taruna of Cangkudu Village still found difficulties in dividing their time between to be actively produce newspaper and their main job. In the implementation of issuing the village newspaper, there were several obstacles, one of them was time availability of the journalist team of Cangkudu Team. The first issue of newspaper which was planned to be in May 2019 was postpones due to incomplete content targeted.

2) The production model of the village newspaper is printed media format. The printed media production process assumed that all material contents have been prepared to be edited and layout. The printed media could be issued when all articles of the agenda setting fulfilled. The problem emerged when the minimal article target was not fulfilled so that the next stage of layout and printing was inhibited.

3) The low level of capability and skill in writing news. Such condition caused longer time in the process of collecting, writing and editing the content.

4) Top down village leadership patter; this one direct leadership contained the consequence of the Journalist team which tended to be passive in sharing their willingness and obstacles in the implementation. For example, it was for asking the data of company CSR managed by the village, as one one the content for the CSR rubric.

5) There was no incentive for the journalistic personnel. It cannot be ignored that it indirectly affects the journalistic team's motivation to make the village newspaper. This was due to the other priority activity which was considered to be more beneficial. 
6) The transition ad succession period of the chief of the village. During the program implementation, local political condition was on the leadership transition period. Village Democratic Party in terms of selecting the chief of the village obliged the chief of the village to take a break until he was chosen definitively as the new chief of Cangkudu Village. Such condition inhibited the coordination and the continuation of the village newspaper publication program.

By through various obstacles encountered, there was still achievement achieved by the village journalistic team. The village journalistic team was success in writing several articles in the form of news. It is noted that this article stop in editing table and has status of waiting other articles for layout.

\section{e. The modelling of assistance based on mass communication media}

From the implementation process of the Community Service, the writer reflected the learning experience and process with the assistance group in an assistance and villagers' empowerment model based on mass communication media. This model can be used one of projections to plan a community service aiming to implement media literacy to the villagers. Model produced is not a standard model, but also can be a benchmark in writing plan and empowerment program. The writer realized that this model needs to be tested continuously considering that the village contex in Indonesia is very dynamic.

\section{Picture 1.1 Modelling of assistance based on mass communication media}

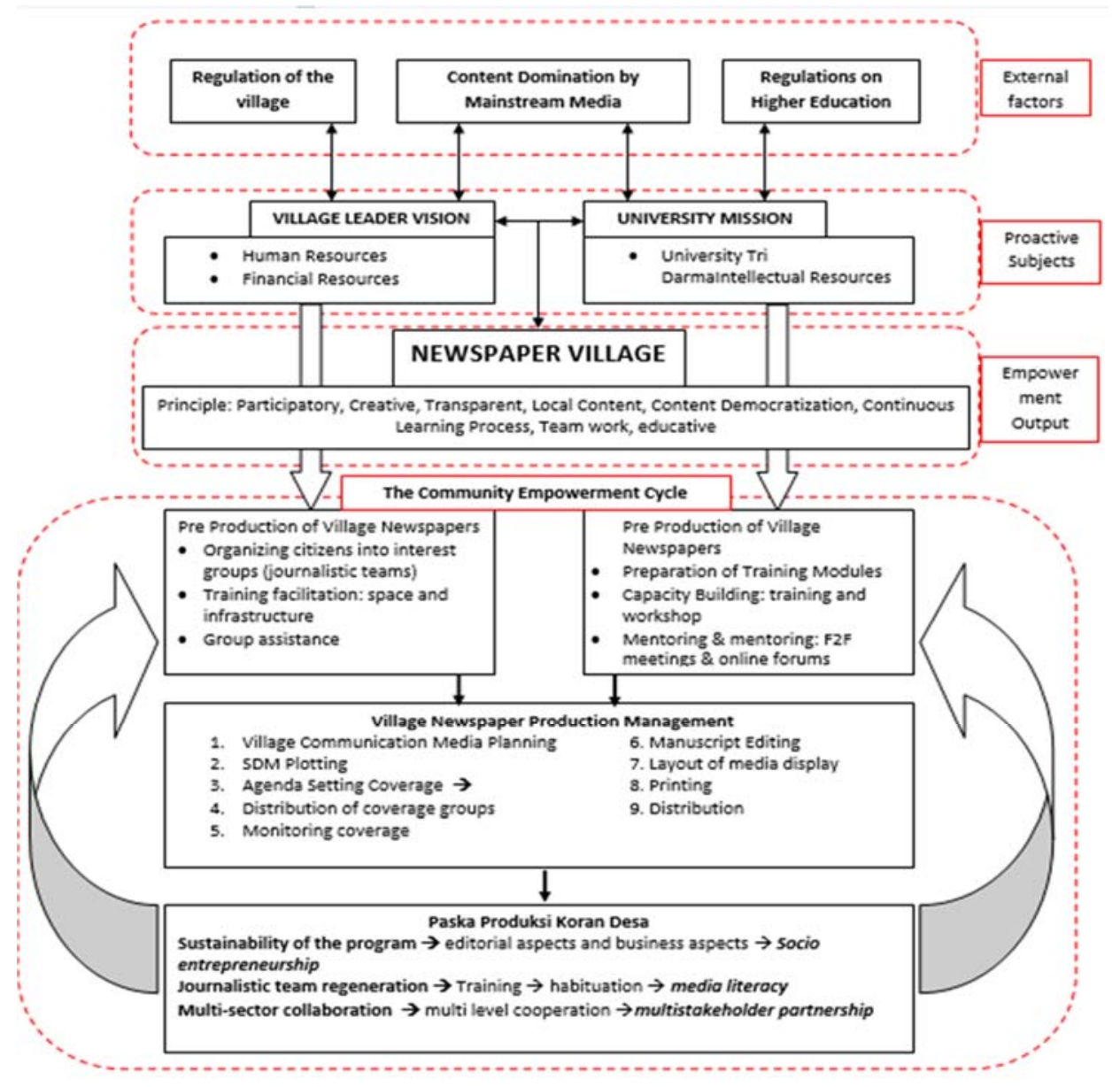




\section{Conclusion}

The implementation of Community Service through Cengkudu Village newspaper program was conducted until the stage of improving the capacity of the village human resource. Journalistic training both in terms of formal and informal has been implemented according to the target. Furthermore, obstacles were found before the publication of the newspaper. Such condition affects the execution of the village newspaper inhibited. There is a need for further coordination with the village and journalist team to find solution which can make all parties easier in starting the production of positive and inspiring content.

Suggestion that can be proposed is changing the form of the village newspaper in which previously is conventional (printed media) into village newspaper in the form or digital or news portal. News portal enables the news publication process without waiting for the other contents preparadness. For the initial publication, the content making can be taken from general them regarding the village, so that it makes the data collection easier. The data collection can be done through literature study available in the village and in the village library. It is expected that it will factes and motivate as well as increase the content to be more specific related to Cangkudu Village.

\section{References:}

Romel Tea. (2014). Dasar-Dasar Jurnalistik untuk Pemula. Retrieved from https://www.romelteamedia.com/2014/04/dasar-dasar-jurnalistik-untuk-pemula.html

Umar Farooq. (2015). Journalism Meaning, Definition and Scope of Journalism. Retrieved from http://www.studylecturenotes.com/journalism-mass-communication/journalism-meaning-definition-andscope-of-journalism 